\title{
ABNORMAL SPERMATHECAE NUMBERS IN PERUVIAN SANDFLIES (DIPTERA: PSYSCHODIDAE).
}

\author{
Elena OGUSUKU' ${ }^{1}$, Enrique PÉREZ ${ }^{2}$
}

\begin{abstract}
We report and illustrate two abnormal spermatheca numbers found in Peruvian sandflies, a supernumerary spermatheca in Lutzonyia carrerai and the absence of one spermatheca in L. amazonensis.
\end{abstract}

Key words: Lutzomyia, abnormal spermatheca, Peru.

Números Anormais de Espermatecas em Flebótomos Peruanos (Diptera: Psychodidae).

RESUMO - Apresentamos e ilustramos duas espermatecas de flebótomos peruanos registradas com números anormais; uma espermateca supernumerária em Lutzomyia carrerai e a falta de uma espermateca em $L$. amazonensis.

Palavras chave: Lutzomyia, espermatecas anormais, Peru.

\section{INTRODUCTION}

Anomalies in the number of different sandfly (Diptera: Psychodidae) structures are most frequently found in males; supernumerary style spines are most common. In females, a frequent abnormality found is in the number of cibarial teeth (FELICIANGELI et al., 1985). Anomalies in the shape or in the number of spermathecae are reported to be associated with gynandromorphism, such is the case of the obstruction of one individual duct reported by SHERLOCK (1958) and the undevelopment of one spermatheca reported by RIOUX et al. (1974) and HARRAT et al. (1993).

Female Lutzomyia sandflies normally have two spermathecae. In this paper we report two cases of abnormal numbers of spermathecae detected in Peruvian Lutzomyia sandflies from the tropical forest Eastern to the Andean Cordillera.

\section{MATERIALS AND METHODS}

The sandfly material The Lutzomyia individuals used for this study were identified and separated from the sandfly collection deposited in the Entomology Laboratory of the Instituto de Medicina Tropical Alexander von Humboldt, Universidad Peruana Cayetano Heredia, Lima, Perú. The specimens separated were: one specimen of Lutzomyia carrerai (BARRETTO, 1946) with a supernumerary spermatheca and one specimen of L. amazonensis (ROOT, 1934) with the absence of one spermatheca.

The specimens were clarified with $\mathrm{NaOH} 10 \%$, treated with lactophenol $(3: 4, v / v)$ and mounted in slides with Canada Balsam.

\section{RESULTS AND DISCUSSION}

Two specimens of Lutzomyia spp. from Perú were found with abnor-

1 Instituto de Medicina Tropical Alexander von Humboldt, Universidad Peruana Cayetano Heredia, Apartado 4314, Lima-100, Peru. 
mal spermatheca numbers. A brief description of them follows:

1.- A female specimen of Lutzomyia carrerai was found with one supernumerary spermatheca (Fig. 1a). The shape of the abnormal third spermateca differs from the other pair. Measurements of all three spermatecae differ from those of normal individuals caught from the same place (Table 1). The imbricated rings of the third abnormal spermatheca are irregularly inflated, the individual duct is "connected directly to the middle of the common duct of the other pair. The

Table 1. Measurements of spermathecae Peruvian Lutzomyia carrerai from normal individuals (NI) and, from a specimen with supernumerary spermathecae, the normal pair (NP) and the supernumerary spermatheca (SS). The measures are given in $\mu \mathrm{m}$.

\begin{tabular}{lrrr}
\hline & NI & NP & \multicolumn{1}{c}{ SS } \\
\hline Number of rings & $9-10$ & 10,1 & 8 \\
Head length & $8.6^{*}$ & $7.6^{\star *}$ & 7.6 \\
Spermatheca length & 46.7 & 37.2 & 32.6 \\
Spermatheca width & 15.9 & 17.4 & 13.9 \\
Individual duct length & 23.9 & 17.4 & 16.3 \\
Individual duct width & 6.4 & 8.1 & 7 \\
\hline
\end{tabular}

${ }^{*}$, Mean of spermathecae of 10 specimens.

** Mean of the 2 spermathecae.

spermatheca body and the individual duct are smaller in the third abnormal spermateca than the other pair. From the normal 4 horizontal cibarial teeth, only vestiges of a central one are present (Fig. 1b).

This specimen was found in a collection of 482 females of $L$. carrerai from Coloradito (Pillcopata, Cuzco), at $1000 \mathrm{~m}$ above sea level, it was caught using CDC light traps in primary rain forest, on August 9, 1989.
2.- A female specimen of Lutzomyia amazonensis was found with the absence of one spermatheca (Fig. 2). The spermatheca present is indistinguishable from that of normal individuals. The individual duct appears to be longer, but its basal portion represents the common duct of the normal specimens.

This specimen was found in a collection of 69 females of L.amazonensis from Veinticinco de Diciembre (Yurimaguas, Loreto), at $220 \mathrm{~m}$ above sea level, and was caught using a Shannon trap with protected human bait, placed in secondary forest, on July 3, 1991.

The mechanisms causing abnormal spermatheca numbers in sandflies, or the physiological consequences and implications for their role as Leishmania vectors were not described. Both species mentioned here are highly anthropophilic, and $L$. carrerai was found naturally infected with Leishmania braziliensis (DESJEUX, 1992), and L. amazonensis was recorded infected with flagellates (LAINSON et al., 1973).

\section{ACKNOWLEDGEMENTS}

We thank M. Cabanillas for providing the material of L. amazonensis and K. Jones, Department of Medical Illustration, Liverpool School of Tropical Medicine, UK, for his photographic work. This study was partially funded by UNDP/World Bank/WHO Special Programme for Research and Training in Tropical Diseases, Switzerland. 


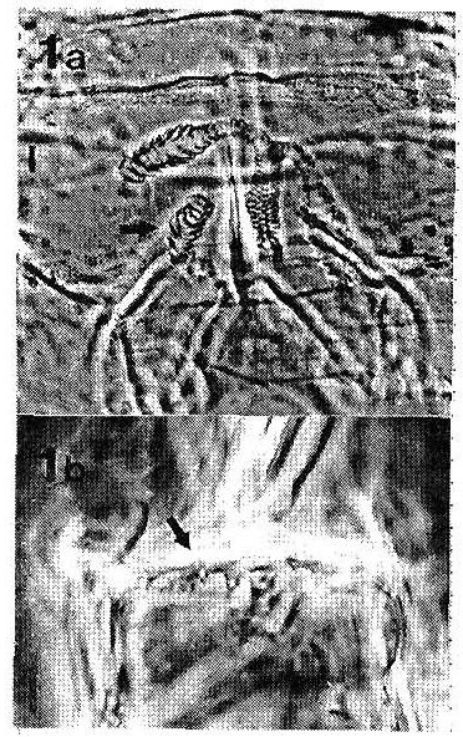

Figura 1a. Last abdominal portion of the female specimen of Lutzomyia carrerai from Coloradito (Pillcopata, Cuzco) showing a supernumerary spermatheca (arrow). Figura 1b. The cibarium of the same specimen with only vestiges of horizontal tecth (arrow).

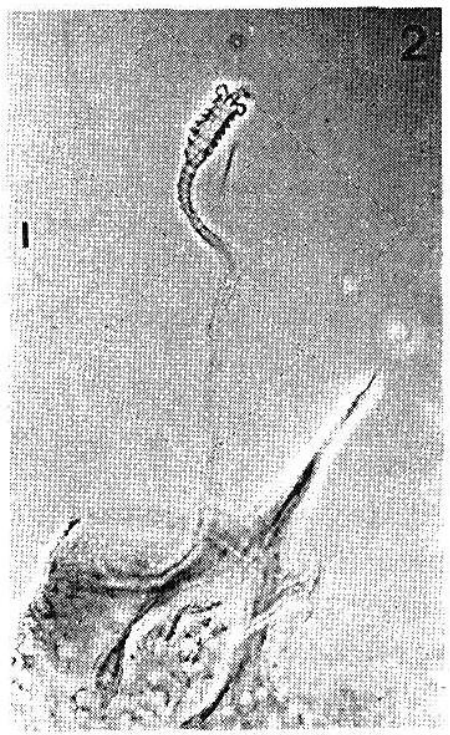

Figura 2. Last abdominal portion of the Lu. amazonensis female specimen from Veinticinco de Diciembre (Yurimaguas, Loreto) showing one spermatheca lacking. The bars are equivalent to $10 \mathrm{im}$. 


\section{Literature Cited}

DESJEUX, P. 1992. Information on the Epidemiology and control of the Leishmaniasis by country or territory. Geneva, World Health Organization. $47 \mathrm{pp}$.

FELICIANGELI, M. D.; ORDOÑES, R.; AGUILAR, C. M. 1985. Anomalies of sandflies in Venezuela. Acta amazonica, 15: 157-166.

HARRAT, Z.; LAMBERT, M.; TABETDERRAZ, O.; DEDET, J. P. 1993. Apropos d'un cas de gynandromorphisme chez Sergentomyia minuta parroti (Adler \& Theodor, 1927) (Diptera, Psichodidae). Bulletin de la Societe Entomologique de France, 98: 459-462.

LAINSON, R.; SHAW, J. J.; WARD, R. D.;
FRAIHA, H. 1973. Leishmaniasis in Brazil. IX. Considerations on the Leishmania braziliensis complex: Importance of sandflies of the genus Psychodopygus (Mangabeira) in the transmission of $L$. braziliensis braziliensis in North Brazil. Transactions of the Royal Society of Tropical Medicine and Hygiene, 67: 184196.

RIOUX, J. A.; ABONNENC, E.; BAUDONY, J. P. 1965. Un cas de gynandromorphisme chez Phlebotomus ariasi Tennoir (Diptera: Psychodidae). Bulletin de la Societe Entomologique de France (NS), 3: $615-$ 617.

SHERLOCK, I. A. 1958. Anomalias de Phlebotomus longpalpis Lutz \& Neiva, 1912 (Diptera: Psychodidae). Revista brasileira de Biologia, 18: 433-437. 